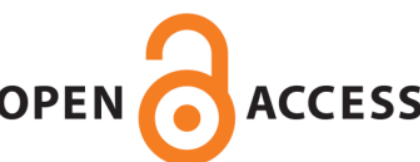

OPEN ACCESS

UWS Academic Portal

\title{
Witnessing entrepreneurial perceptions and proclivity in university students
}

Murray, Alan; Crammond, Robert

Published in:

Education + Training

DOI:

10.1108/ET-03-2019-0052

Published: 26/06/2020

Document Version

Peer reviewed version

Link to publication on the UWS Academic Portal

Citation for published version (APA):

Murray, A., \& Crammond, R. (2020). Witnessing entrepreneurial perceptions and proclivity in university students: developing a process model. Education + Training, 62(4), 459-481. https://doi.org/10.1108/ET-03-2019-0052

\section{General rights}

Copyright and moral rights for the publications made accessible in the UWS Academic Portal are retained by the authors and/or other copyright owners and it is a condition of accessing publications that users recognise and abide by the legal requirements associated with these rights.

Take down policy

If you believe that this document breaches copyright please contact pure@uws.ac.uk providing details, and we will remove access to the work immediately and investigate your claim. 


\title{
Witnessing Entrepreneurial Perceptions and Proclivity in University Students:
}

Developing a Process Model

\author{
Alan Murray and Robert Crammond, 2019 \\ University of the West of Scotland
}

\section{Purpose}

This paper analyses the transition of university students from initial perceptions of enterprise to potentially heightened levels of proclivity towards creative behaviours and future entrepreneurial activity.

\section{Literature}

Fundamental aspects central to enterprising education such as the equipping of businesses becoming more entrepreneurial, the embedding of enterprise within university, and noted literature concerning motivation, intention, and enterprising activity are visited to critically construct the questioning posed. A thematic approach is utilised, in ascertaining enterprising notions, which aid in the formulation of our Entrepreneurial Scorecard, designed to provide a measure of relevant traits within students.

\section{Approach}

Adopting a positivist approach, an intention-based scorecard survey targeted to two cohorts totalling 75 undergraduate students leading to 150 responses at a Scottish university. These were circulated at start and end sessions of four relevant courses, to establish a measure for selfevaluation with respect to perception and proclivity.

\section{Findings}

The data gathered from the Entrepreneurial Scorecard emphasised differences in perception and proclivity between the two cohorts, namely creativity, risk-taking, leadership, and business aspiration. This re-emphasised the three, identified themes: awareness through trait identification; autonomy through developing enterprising skills; and achievement through practicing entrepreneurial activities. This formed the basis for our novel model in supporting the entrepreneurial development of students: The Perception to Proclivity Process Model.

\section{Contribution}


The practical output of this research is a novel tool for evaluating entrepreneurial perceptions and proclivity through the scorecard. This study adds to the existing research base around entrepreneurial intention and action whilst providing a new model for a guiding framework for the entrepreneurial student and educator journey.

\section{Value}

This paper's approach outlines many themes and inherent questions of concern to enterprise educators and university management towards the creation, maintenance, or development of an enterprise course or programme. This research introduces the concepts of entrepreneurial perception and entrepreneurial proclivity, explaining the important role they play in developing students. Additionally, the scorecard has potential for application in a longitudinal context as a means of establishing potential shifts in entrepreneurial perception and proclivity. However, the application is not limited to the scope of higher education, with clear potential to apply this tool and approach within other domains.

\section{Limitations}

This study focusses on a single case and further research within other institutions and domains is encouraged to contextually test the transferability of the two key outputs: the Entrepreneurial Scorecard and the Perception to Proclivity Process Model.

\section{Keywords}

Enterprise Education, Higher Education, Entrepreneurial Perception, Entrepreneurial Proclivity, Entrepreneurial Intention. 


\section{Introduction}

As individuals, or within educational institutions, we naturally hold beliefs, perspectives and opinions of enterprise and entrepreneurialism. The emergence of new, and continual facilitation of successful, university courses and degree programmes, are a product of many factors (Marques et $a l ., 2012)$. These factors include institutional expertise, student demand, industry and societal need, and fluctuating market changes (Marzo-Navarro et al., 2012; Ahmed et al., 2019). As for entrepreneurship education, these types of courses and programmes, and related forms of enterprising education, are now a mainstay within higher education institutions globally (Kuratko, 2005; Casson, 2010; Oosterbeek et al., 2010).

Notable studies within the field have been conducted, which have aimed to capture the perspectives, opinions, and emotions of students and educators, who are engaged in entrepreneurship and enterprise education (Krueger et al., 2000; Fayolle, 2005; Bae et al., 2014; Eid et al., 2019). However, difficulties are noted around the evaluation of programmes and approaches to enterprise education aimed at determining and measuring effectiveness (Henry et al., 2005; Fayolle et al., 2006). One such aspect of this journey, is witnessing a change or transition in the students' intention or proclivity towards entrepreneurial behaviour after completing a given course. This paper investigates this aspect, focussing on one university within the United Kingdom.

Both entrepreneurship and enterprise education are well-researched fields (Fayolle, 2005; Souitaris et al., 2007; Fayolle and Gailly, 2015) and whilst much of this research focusses on how enterprising education, in general, supports the goal to establish routes to improved rates of entrepreneurial behaviour amongst students and graduates (Galvão et al., 2018) problems still exist around measuring its effectiveness (Fayolle et al., 2006; Bae et al., 2014; Eid et al., 2019). This Entrepreneurial Perception, referred to in this paper as $e P e r$, may be either positive or negative in nature and will affect their approach to the subject, as well as the decisions they make within their academic journey. This impacts requirements to advance intention models and engage with the factors and motivators towards entrepreneurialism (Zhang et al., 2014; Eid et al., 2019). With the intervention and experience of engaging in a relevant course or programme, these beliefs and perceptions can be tested towards realising academic aptitude, and proclivity towards such activity. This Entrepreneurial Proclivity, referred to in this paper as ePro, is the result of the increased potential for future, enterprising behaviour. This is expressed through renewed skills, notable traits, raised awareness of individual entrepreneurial capability, and changed behaviours. This paper discusses the various factors, out with and within the educational context that affects and positively encourage this process. 
Having considered issues in designing, delivering, and measuring enterprising forms of education within higher education, this paper focusses on the following question: to what extent can universities suitably measure the entrepreneurial proclivity of their students, in practical response to their own contextual conditions and institutional ethos and ambitions?

The aim of this paper is to measure and conceptualise the student journey, by recording the transition towards $e$ Pro. This is with respect to the university's targeted values and intentions of the courses investigated.

This paper responds to this question with a deductive, 'theory-building' approach, which visits the question through a review of extensive and extant literature, in developing testable hypotheses. This process of data collection aims to address the unique, institutional ethos within a practical, enterprising setting: the undergraduate classroom. The question leads this paper into directed and refined areas of previous literature, in order to shape the empirical phase of this research. The hypotheses are constructed to highlight the thematic aspects of the student journey and potential ePro that this paper wishes to investigate analytically, through behavioural-based questions and variable analysis. These questions take the form of variables, as cross-thematic relationship analysis is undertaken to assert the tendency of $e$ Pro.

The literature firstly introduces a historical background, including initial ideologies of entrepreneurship. In accordance with this paper's central question and overarching aim, the discussion progresses to the intervention of entrepreneurship within higher education. This includes discussing the impact of enterprise on the student experience and the advancing journey towards employment, self-employment, and enterprising behaviour. In achieving this, a review of recent studies investigating entrepreneurial tendencies, creative and innovative activities, and measuring raised entrepreneurial intentions of students is undertaken. These realisations are reached through engagement that is both practical and student-centric.

This is then followed with brief detail of the institutional context researched: measuring and comparing the impact within the University of the West of Scotland during the $2018-2019$ session.

The section following these outlines the methodological approach and sampling strategy for the study, including hypothetical reasoning. Then, the findings from the empirical phase are described and reflected upon, with relationship analysis as per thematic variable also scrutinised. The concluding sections of this paper discusses the bearing of these results, through revisiting the stipulated hypotheses and the introduction of the paper's novel process model which illustrates the contextual journey witnessed. Furthermore, the theoretical and practical implications of this study, and the recommendations for future research and practice, are summarised. 


\section{Background}

The practice of entrepreneurship is as old as the human race itself, where entrepreneurs were viewed as an important class, central to economic change (Schumpeter, 1934). History demonstrates that entrepreneurs exist from many backgrounds, and definitions of entrepreneurship can be found stretching back many centuries. Many of these definitions focus on concepts such as uncertainty and risk (Knight, 1921) or decisive action taking (Casson, 1982), remaining key themes in the field of entrepreneurship. According to Drucker (1985), successful entrepreneurs see potential opportunity in their external environment from factors such as demographic changes, new knowledge, and changes in perception, mood, and culture. Historically, capitalising on these opportunities often required the entrepreneur to challenge traditional ways of thinking and doing, and this contributed to the popular image of the entrepreneur as a 'maverick' or 'rule breaker' (Pinchot, 1986).

Much of the research around entrepreneurship is focussed on trait theory, which seeks to identify successful behaviours and characteristics (Formaini, 2006). From this, there has been considerable debate over the years regarding whether entrepreneurs are born or made: the "nature v nurture' debate (Shefsky, 1994). Most researchers, however, agree that some common traits and qualities are likely to be found in the successful entrepreneur (Eckhardt and Shane, 2003). Bolton and Thompson (2005) define an entrepreneur as a person who innovates to create value around opportunity. The entrepreneur applies creativity to turn opportunity into practical reality through the innovation process (Burns, 2013). Davidsson (2015) states that in order to fully understand why entrepreneurship occurs there is a need to examine the individual, the opportunity, and how these elements fit. This is referred to as the individual-opportunity nexus. Entrepreneurial individuals undoubtedly have different skills from others and these skills enable them to make judgments in order to coordinate scarce resources and make do with what they have (Grichnik et $a l ., 2014)$. Whilst it is generally believed that these qualities can be developed in the individual through enterprising education (Neck et al., 1999; Von Graevenitz et al., 2010), some researchers have questioned the impact of such interventions on the entrepreneurial skills development and intention of the individual (Oosterbeek et al., 2010).

The terms enterprise education and entrepreneurship education are often used to mean the same thing (Jones and Iredale, 2010), however the goal of both is to establish routes to improved rates of entrepreneurial behaviour amongst students and graduates (Galvão et al., 2018). There is also a move to address the bias in enterprise education towards business start-up leading to a more 
mainstream view of enterprise which sits out with entrepreneurship (Mwasalwiba, 2010) and encompasses entrepreneurial activity within corporate settings (Casson, 2010).

\section{The Educational Impact}

It can be useful to think of the entrepreneurial development process around perception and proclivity not in linear terms but as a learning cycle (Taatila, 2010) which supports the development of entrepreneurial competencies (Marzo-Navarro et al., 2009). In higher education, a common response to market need is to develop a set of graduate competencies which are aligned to these themes, measuring the effectiveness of enterprise interventions (Duval-Couetil, 2013). Research confirms that whilst entrepreneurship education is widely believed to have a positive impact on student entrepreneurial intention and action, the extent of this impact is unclear, and measurement of this phenomenon is problematic (Pittaway and Cope, 2007; Ahmed et al., 2019). As a result, there is a lack of empirical evidence around how learning strategies impact directly on entrepreneurial competences and how these competences transition into venture creation (Garavan and O'Cinneide, 1994). Much has been written about models of entrepreneurial intention, which is a determining factor influencing entrepreneurial action, and around the role education can play in delivering entrepreneurial outcomes (Costa et al., 2016). Numerous models have been developed which focus on entrepreneurial intention (Bird, 1988) such as those of Shapero and Sokol (1982) who explain how perceived desirability, feasibility, and propensity to act lead to entrepreneurial intentions. Liñán et al. (2011) propose their own model for explaining entrepreneurial intentions which cites personal attitude and perceived behavioural control as key drivers. Other models of entrepreneurial intentions combine attitude and behavior theory (Ajzen, 1991), or integrate social learning theory with self-efficacy theory (Bandura, 1986). Some researchers have developed and tested their own measures of entrepreneurial intention exploring aspects such as innovativeness, risk-taking, and proactiveness (Langkamp et al., 2012). However, the wider research shows that there is a need for additional study around the use of impact indicators related to emotion and mind-set (Nabi et al., 2017) and also the part played by other factors such as specificity and duration of education interventions, as well as background and culture (Bae et al., 2014). The research shows that entrepreneurial intent and entrepreneurial behaviour are inextricably linked (Reynolds, 1995) however our perception of entrepreneurship and the likelihood that we will become entrepreneurs is influenced by internal and external factors (Schwarz et al., 2009).

As the entrepreneurial research outlines, and for many forms of enterprising education to flourish, students must evidence attributes such as (self or market) awareness, (personal) 
autonomy, and achievement. This study is mindful of these, in the formulation of the questions used here.

\section{The Institutional Context}

The University of the West of Scotland (UWS) was formed in 2007, following a merger between Paisley University and Bell College. UWS offers a broad range of programmes from campuses in Ayr, Dumfries, Lanarkshire, London, and Paisley. Although officially a new university, UWS draws from a long history from the education institutions which contributed to its formation. In the case of UWS, the institution's aspirations for entrepreneurial development are articulated through a set of graduate competencies termed 'I am UWS' (Table 1). Graduate attributes are those important qualities which are intended to prepare the student for life and work. These attributes outline what the university regards as key traits and abilities which should be apparent within aspiring individuals: personally, interpersonally, and professionally.

The aim of 'I am UWS' is to act as a blueprint for developing student attributes in the three key spheres: academic, personal, and professional. The objective is to develop graduates who are universal, work ready, and successful. Universal is explained as being globally relevant with comprehensively applicable abilities, skills, and behaviours. Work ready is defined as being dynamic and prepared for employment in ever-changing environments which require lifelong learning and resilience. Successful is categorised as being a graduate succeeding and realising their potential across various contexts.

Table 1 UWS Graduate Attributes - 'I am UWS'

\begin{tabular}{|c|c|c|c|}
\hline & Academic & Personal & Professional \\
\hline Universal & $\begin{array}{l}\text { - Critical Thinker } \\
\text { - Analytical } \\
\text { - Inquiring }\end{array}$ & $\begin{array}{ll}\text { - } & \text { Emotionally } \\
& \text { Intelligent } \\
\text { - } & \text { Ethically } \\
& \text { Minded } \\
\text { - } & \text { Culturally } \\
& \text { Aware }\end{array}$ & $\begin{array}{l}\text { - } \quad \text { Collaborative } \\
\text { - Research Minded } \\
\text { - Socially } \\
\quad \text { Responsible }\end{array}$ \\
\hline $\begin{array}{l}\text { Work- } \\
\text { Ready }\end{array}$ & $\begin{array}{l}\text { - Knowledgeable } \\
\text { - } \quad \text { Digitally Literate } \\
\text { - Problem Solver }\end{array}$ & $\begin{array}{ll}\text { - } & \text { Effective } \\
& \text { Communicator } \\
\text { - } & \text { Influential } \\
\text { - } & \text { Motivated }\end{array}$ & $\begin{array}{ll}\text { - } & \text { Potential Leader } \\
-\quad \text { Enterprising } \\
\text { - Ambitious }\end{array}$ \\
\hline Successful & $\begin{array}{l}\text { - Autonomous } \\
\text { - Incisive } \\
\text { - Innovative }\end{array}$ & $\begin{array}{l}\text { - } \text { Creative } \\
\text { - Imaginative } \\
\text { - Resilient }\end{array}$ & $\begin{array}{l}\text { - Driven } \\
\text { - Daring } \\
\text { - Transformational }\end{array}$ \\
\hline
\end{tabular}


As aforementioned, the research question summarises the central focus of this paper which coincides with the above table of attributes. This focus is witnessing, and measuring, the transition and development of students, from initial perceptions of entrepreneurship to raised proclivity and intention, using a method of data collection. The above literature provides further clarity on the core and surrounding themes and entrepreneurial stages, which aids the formulation of the measurement tool used.

Given the review of the literature, this paper categorises the student and educator, entrepreneurial journey by the definitive stages: Programme Introduction and Topical Orientation (Start); Creative Activities (Stage 1); Innovative / Developmental Activities (Stage 2); Entrepreneurial / Planning \& Coordinating Activities (Stage 3); and, Assessment / Impact \& Reflection (Finish). These represent the evolving journey and are coupled with UWS-inspired questioning in Table 2. Figure 1 illustrates the conceptual framework, which displays typical phases of enterprising courses (creative to developmental to assessment) and notes the emotive themes highlighted within this study and expectantly experienced:

\section{Figure 1 Hypothetical Development}

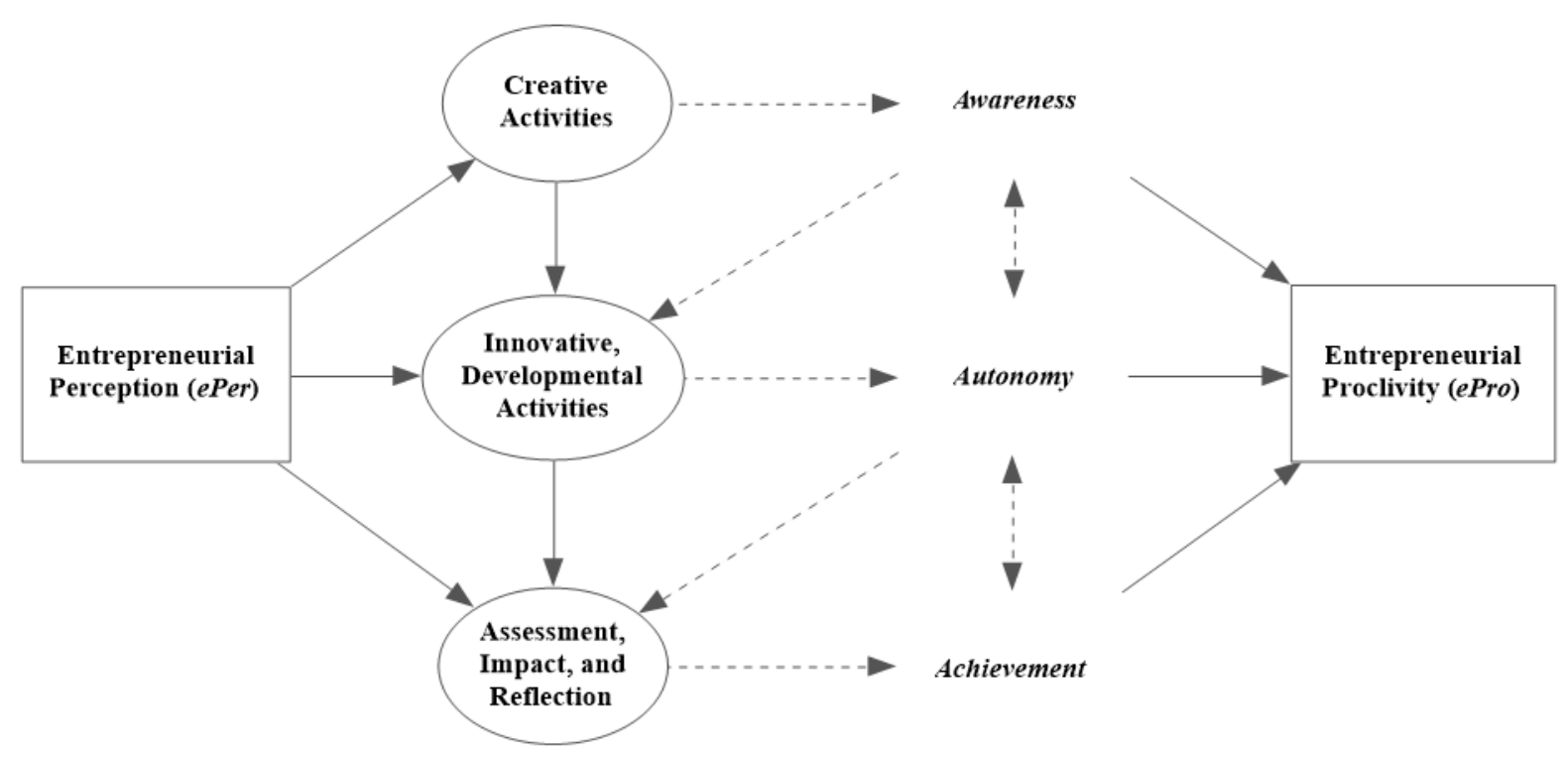

The following statements present the hypotheses taken to the empirical study:

\section{Awareness}


HP1 - Proclivity towards continued creative and idea generating activities increase, at end course stage.

\section{Autonomy}

HP2 - Entrepreneurial planning and perceptions of market awareness and accommodating increased risk increases, at end course stage.

\section{Achievement}

HP3 - Students' proclivity towards continued small business and entrepreneurialism increases, at end course stage.

These hypotheses are tested, analysed, and commented on in the latter sections of this paper. Table 2 lists the twenty-five questions of the scorecard, by stage and attributed theme.

\section{Approach}

This paper follows an expectant, 'theory-building' process of review-informed data collection, towards analysing new findings and reflecting on past assertions and conceptualisations. A justifiable, methodological profile must be discussed, including addressing the philosophical, practical, and analytical aspects of such an investigation.

As discussed earlier in this paper, this research follows a deductive approach. This was deemed appropriate for three reasons. Firstly, the research question leads into a review of the literature which informs the formulation of the stages and Entrepreneurial Scorecard questions. Secondly, a deductive approach supports the conceptualisation of the paper's novel model itself, advancing from secondary literature. Thirdly, this constructive reasoning of the model encourages wider application within other domains, educationally and industrially.

With a suitable, intention-based survey method utilised, a positivist philosophy is attributed to this study. As the three testable hypotheses are formulated, having reflected upon the secondary information, the positivist philosophy concurs with the paper's aim of failing to disprove, or confirm rejection of, relevant hypothetical statements stemming from the research question. An interview method could be sought for a study and sample such as this. However, a lack of numerical coding to responses (unfavourable to favourable), with a purely interview method, would weaken and impair the performance of comparative analyse. Also, considerable time would be spent on interviewing a large sample twice, to meet the demands of the before and after nature of this study, and survey distribution. This would also be the case if adopting a focus group scenario. 
This method of data collection is in the form of a quantitative survey, named here as the Entrepreneurial Scorecard. The purpose of the Entrepreneurial Scorecard is to provide some insight for the student in the areas of ePer and ePro. This concerns the nurturing of enterprising skills, as aligned with notions of business and entrepreneurship (Bridge, 2017) and understanding secondary and tertiary factors (Ustav and Venesaar, 2018). The scorecard realises the need to evaluate and gauge perceptions and beliefs surrounding enterprise, as expressed by Liñán et al. (2011) and Marques et al. (2012) for example. The twenty-five questions contained within the Entrepreneurial Scorecard cover key entrepreneurial characteristics clearly aligned to these graduate attributes such as attitude to risk, creativity and problem-solving, and working with and leading others. The scorecard response scores range from 1 to 4 ; 1 representing unfavourable, infrequent, or disagreement to the question, to 4 representing favourable, frequent, or agreement to each question. The questions themselves are subjective, with no right or wrong answer.

Having completed the Entrepreneurial Scorecard, the student is asked to reflect on their score before considering four questions. The aim of this phase is to provide an insight into individual $e P e r$.

The questions are: (1) What was your score? (2) What do you feel is getting in the way of a higher score? (3) What could you do to overcome this? (4) From these results, do you feel you are enterprising or entrepreneurial?

The participants are then asked to reflect on their ePro by considering four key statements and identifying which best applies to them. These statements are as follows; I can see myself running my own business someday - this implies they have a clear interest in possibly running their own business in the future. I can see myself running someone else's business someday - here we are talking about managing a business they will not own themselves. I'd rather just work in someone else's business - this suggests that, at present, they do not desire to start a business or manage someone else's. Or I'd rather do something else - there are other possibilities here which must be considered which could be potential graduate destinations such as choosing not to work at all, continuing in education, or undertaking training.

By completing the Entrepreneurial Scorecard, and discussing the insights gained from this, the student is able to identify relevant strengths and weaknesses. From this, the student is then encouraged to consider what actions they can take to develop these qualities in line with the range of attributes stipulated.

\section{Sampling}


For this study, purposive sampling was used. The empirical study within this research involves a cross-sectional control group, as opposed to a longer-term, longitudinal study. The former was selected to capture perspectives and measure responses from two, distinctive student cohorts within the academic year. Also, the decision was taken to apply a cross-sectional approach with data collected at two, distinct points, in order to test the effectiveness of the Entrepreneurial Scorecard as a measure of ePer and ePro. This would also allow the data to be analysed, in determining shift in results, following the intervention of the courses.

The two cohorts were (1) daytime students within the university's undergraduate business programme, which includes a summer school cohort $(n=50)$; and (2) mature, evening, and distance learning students undertaking an industry-sponsored programme $(n=25)$. The evening and distance learning programmes are also certificated at undergraduate level.

The ages of the participants ranged from 18 to 50, with a 57:43 female, male gender ratio. These cohorts of students were registered across, but not within all, four courses. These were held during the 2018 - 2019 academic session and were delivered by the authors of this paper. These four courses focussed on (1) enterprise and business creation; (2) business acceleration; (3) leadership and management; and (4) creativity and innovation. The scorecards were introduced as a tutorial activity at two stages of the courses mentioned above: start and end. A total of 150 comparable responses were recorded.

Before distribution, the scorecard questions were discussed openly within the classroom, highlighting the inferred themes and topics of relevance to the student's personal and professional development. Therefore, the questions themselves encourage students to discuss and participate in the survey. It contributes to course content, and the students' increased knowledge and understanding of enterprise and entrepreneurship. Nevertheless, although part of the formal course outline of tutorial activities, participation was voluntary.

Descriptive analysis is undertaken to document and display the scorecard scores in isolation, and their differences between before and after course intervention. This includes an average score calculation for each of the twenty-five questions, as well as average scores per participant, per cohort. These figures display the shift along the 1 to 4 response range, akin to a Likert-scale range, indicating a change in the participant's tendency to disagree or agree to questions posed. Valid comparability is achieved, as all questions within the scorecard survey are unchanged, per cohort, as they are distributed at both start and end stages of the four courses.

Furthermore, correlation, and means and two-tailed, t-Test calculations are displayed to address the validity and reliability of the findings. These tests measured the strength and probability $(p=<0.05)$ of a participant's tendency to change their entrepreneurial perception or 
belief, with respect to the given question. These inform the revisited hypotheses, within the analysis and discussion phases of the findings.

\section{Findings}

The novel introduction of the Entrepreneurial Scorecard proved highly constructive in alerting us to the many perspectives and perceptions of enterprising education. Additionally, it indicated how it is generally received from students within the learning environment. This paper asserts these many considerations in the form of the questions posed, which represent the fears and assumptions that students face when considering their careers and opportunities. As seen within the appendix, these questions are grouped within phases, as per the process model discussed later. This distinctly illustrates the primary objectives and interactions between the learner and student against the progress of an entrepreneurially-focussed course.

The 150 responses uncovered various aspects related to idea generation, innovation, business planning, and marketisation. The results prove beneficial for all forms of entrepreneurship-focussed education: including the development of enterprising skills, and business start-up and idea-to-innovation development. To reiterate, the scorecard response reflects a Likert-style approach with a scores range of 1 to 4 , from unfavourable or disagreement ( 1 and 2) to favourable or agreement respectively (3 and 4). Table's 3 to 7 document the descriptive, relationship, and correlation analysis, which is discussed throughout the remainder of this paper.

\section{Cohort 1}

At the start of the courses, students recorded an average scorecard score of 69.74 , around $70 \%$; thus, generally placing students within the third quartile of tendency ( 3 from 4 ). This is coupled with the average question score of 2.79 , indicating mild, positive agreement to the questions. After completing the survey for a second time, the average scorecard score increased to 76.14 , or $77 \%$. This, with the average question score increased to 3.05, elevates the general outlook from students into firm agreement to the questions posed. Remarkable comments to be made from this daytime cohort were noted. Questions of increased motivation and working hours did not show any change. However, students indicated increased tendency to confront greater risk, and changes to their incomes in order to achieve an entrepreneurial endeavour, competition, increased discipline and perseverance, and considering starting up their own business. This is a direct effect from entrepreneurial activity and positive exposure productive educational environments. Nevertheless, results reported a decrease in tendency towards leadership, aspects of firing and hiring staff, 'living without structure', belief in adaptable skills, and aspects of problem solving. These results are 
potentially due to the dynamic group activities undertaken during the courses. These, as with other disciplines, have variable outcomes to students and their preferred modes of learning.

\section{Cohort 2}

With completion of the first round of surveys, students returned an average scorecard score of 67.56, around $68 \%$. This again placed students within the third quartile of tendency. Similarity was seen with the first cohort, furthermore, with a calculated average question score of 2.70. After completing the survey for a second time, the average scorecard score increased to 74.76 , or $75 \%$. Along with an average question score increasing to 2.99 , this moves the general outlook from students into predominant agreement to the questions posed (3 from 4). Every question returned small, incremental jumps in question score. Interestingly, aspects of motivation, leadership, evidence of relevant business experience, being a multi-tasker, engaging in problem solving, and receiving constructive and developmental advice all returned more notable increases. These workplace-related attributes would tend to coincide with the experiences of generally older participants from this cohort, compared with younger students from cohort 1 . With these experiences comes greater responsibility and initiative in the working environment, leading to greater comfortability with, and agreement to, these notions in the questioning.

Overall, participants within both cohorts indicated a strong ePro towards entrepreneurialism, given the exposure to idea-based and innovative activities. Contemporary learning within the university has further influenced this increased desire to be entrepreneurial, in response to the needs of organisations wishing to employ and work with creative individuals and groups. In essence, the evidence shows the benefits of embedding enterprising, work placement, and internship opportunities which strengthen industrial ties with education. These also aim to embolden the immediate, national, and international enterprising networks.

\section{Analysis}

The findings from the Scorecard further highlighted the themes witnessed during the lifespan of the undergraduate courses that were examined: awareness through trait identification; autonomy evidenced by developing enterprising skills; and achievement through practicing entrepreneurial activities. Table 8 displays the correlative similarities and differences, between cohorts, by appreciating the relationship between paired variables. 


\section{Awareness}

HP1 - Proclivity towards continued creative and idea generating activities increase, at end course stage.

Firstly, the theme of awareness. Students completing the scorecard were posed with critical and somewhat personal questions, involving a self-reflective process related to aspects of enterprise. Investigating whether relevant traits are witnessed, or practiced, by students led to an educationally-based enlightenment which increased motivation and proclivity to enterprise. These traits, including leadership, problem solving, creativity, and organisation, which are consistently discussed within any business sub-discipline, are encountered early into the course to enable students to reflect upon and plan ahead (Zhang et al., 2014; Eid et al., 2019) towards future entrepreneurial activities. Cohort 1 expressed uncertainty about future direction (-0.281) amidst widening opportunity, with self-doubt about their creative instinct (-0.264). On the contrary, cohort 2 indicated greater assurance $(0.317)$, possibly with more experience of enterprise, leading to more course-relevant ideas and topics of discussion. Therefore, students from the latter group reacted positively towards creative activities, as evidenced through the related question responses, thus partially supporting this hypothesis.

\section{Autonomy}

HP2 - Entrepreneurial planning and perceptions of market awareness and accommodating increased risk increases, at end course stage.

Autonomy arises in the educational context from enabling students to take ownership of their work and contribute towards classroom activities (Liñán et al., 2011). Throughout an enterprise course this is initiated through experiences, opinions, and perceptions of entrepreneurship, promoting enterprising activities (Ustav and Venesaar, 2018). The first cohort responded positively towards this theme overall, but result indicate that they were keen for some job security $(-0.053)$. This is evident as younger students with little to no experience of industry wishing to successfully enter the market, upon graduation. Cohort 2 indicate greater confidence and assertiveness, in solving problems $(0.477)$ and multi-tasking $(0.343)$ but are not happy with confronting the hiring and firing aspect of the workplace (-0.130). This could be due to past experiences in employment. In general, again, positive correlations were recorded by students, supporting the second hypothesis.

\section{Achievement}




\section{HP3 - Students' proclivity towards continued small business and entrepreneurialism increases, at end course stage.}

The third theme of achievement marks the end 'goal' of any course aim or learning objective but is multifaceted when it concerns formal delivery of enterprising education (Otache, 2019; Sá, 2019). A credible business plan, effective pitch of a business idea, or personal and professional portfolios all contribute to increased entrepreneurialism (Zhang et al., 2014). Both cohorts felt a sense of achievement in dealing with the pressures of the course expectations and practical assessments $(0.380$ and 0.291$)$. Many were inspired by their efforts at handling this pressure with increased tendency in considering starting their own business $(0.157$ and 0.120$)$. The above assertion was supported by the study conducted, within this theme.

\section{Perception to Proclivity Process Model}

This paper advances our understandings of enterprising education and related intention studies to produce a process model (Figure 2). This model aligns the three identified themes of awareness, autonomy, and achievement to chronological activity stages of an enterprise course: orientation, creativity, innovation and developmental, planning and coordination, and assessment and impact. This new model provides a framework for the entrepreneurial journey of the students, as well as supporting the small business and entrepreneurial context (see also Crammond et al., 2018 and Murray, 2019a).

At the beginning of the journey the graduate competencies can be seen within the learning outcomes which are embedded in the course or programme materials. This orientation phase rests the responsibility of the course on the educators to suitably reflect business realities and enterprise. These realities must be acknowledged against the interests and ambitions of students. The process model then contains three stages and a finish phase of the course.

The first, active stage of the course is concerned with facilitating idea generation. This stage places an initial, and distinct focus, on critical reflection and self-awareness.

The second stage, innovative and developmental activities, assists in enabling business and group dynamics to be realised. This includes delegation and enabling a working team.

The third stage of this transition, titled planning and coordinating activities, affirms the learning outcomes of any enterprising course where typical traits and actions of managers, leaders, entrepreneurs etc., are witnessed. These include conducting the relevant research and organisation, to plan and forecast ahead, in engaging with the marketplace. These traits and actions aid in the building of graduate and employability attributes, as preparation and defending of a business case is practiced. 
The final, outward phase of assessment and impact is evidenced by achievement of the course or module expectations, along with witnessing an added value: idea development and incubation, new business start-up, or newly-established business contacts. 
Figure 2 Perception to Proclivity Process Model

\begin{tabular}{|c|c|c|c|c|}
\hline Start & Stage 1 & Stage 2 & Stage 3 & Finish \\
\hline
\end{tabular}

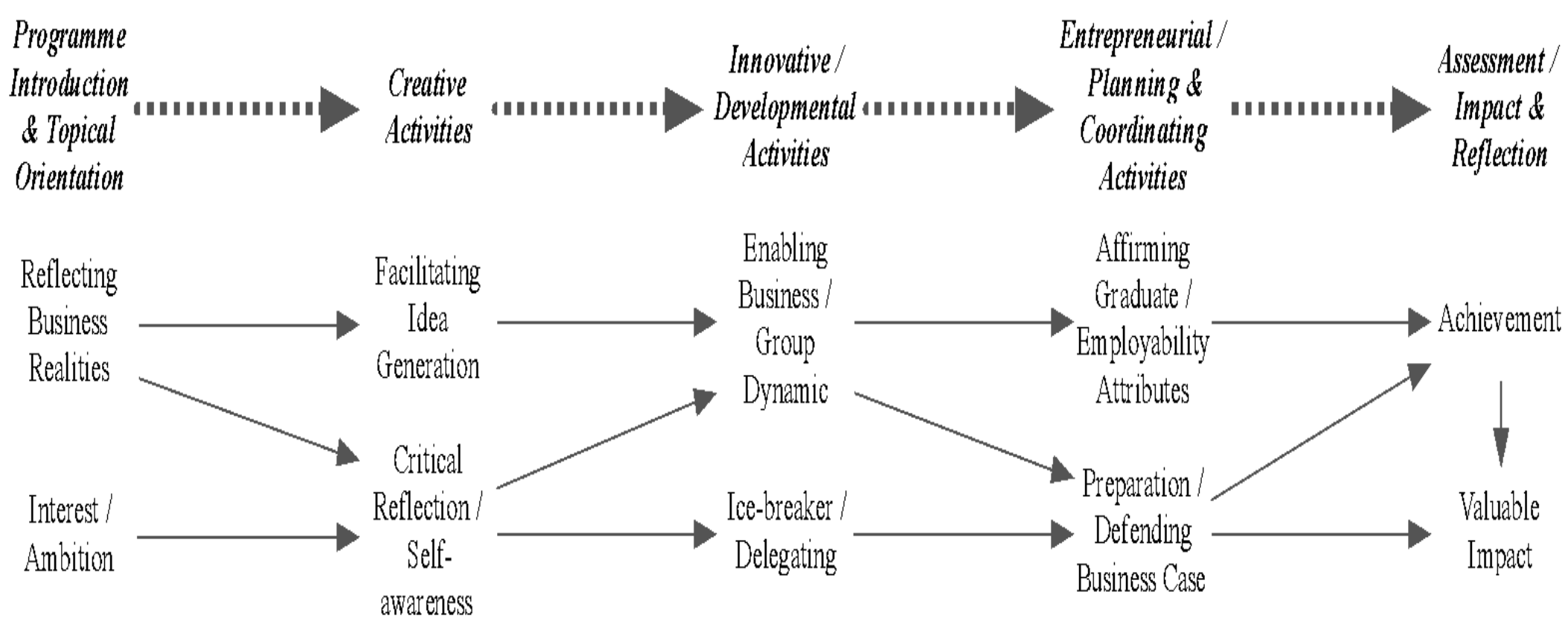

(Inspired by Liñán et al., 2011; Marques et al., 2012; Eid et al., 2019) 
Throughout the course of this journey, the student is exposed to curricular and cocurricular interventions which are grounded in the principles of both practical and valuable entrepreneurial learning (see Murray, 2019b). If successful, the destination for the journey is employment for the graduate who is equipped with the range of competencies. This employment could be in an entrepreneurial or intrapreneurial context. The role of the Entrepreneurial Scorecard is to support this approach, by providing a measure of ePer and ePro to determine to what extent they are equipped for the world of work; in accordance with the core values of the enterprising institution and wider business networks (Crammond, 2019; Murray et al., 2019). It is recognised that this measure is subjective in nature, however represents central questions associated with enterprising education.

\section{Conclusion}

As this paper has noted, similar intention and impact studies of enterprising education have been widely used to assess the benefits and impact of enterprise courses and programmes (Bae et al., 2014; Eid et al., 2019). These are fundamental in shaping the content delivered, methods applied, and assessments posed. Exposure to enterprise courses enlighten and inform students of the topic. However, increasing intentions towards performing it in practice, and becoming entrepreneurial, is another aspect. This practical aspect, which typically requires time to elapse for true enterprising, commercial activity to take place, can be broached with graduate destination or post-certification surveys which seek information from alumni. Over the course of a given module or programme, a comparative investigation using identical variables (questions) allows for the impact of a given education experience to be witnessed. This gives credence to, and adds value, to approaches and methods of advancing enterprising education.

The research question, to what extent can universities suitably measure the entrepreneurial proclivity of their students, in practical response to their own contextual conditions and institutional ethos and ambitions? was addressed through utilising a measure of analysing contextual, enterprising education. The Entrepreneurial Scorecard strengthens this novel approach of communicating with students. This is further represented through self-awareness exercises, the opportunity to influence classroom proceedings, develop graduate attributes, and achieve short to medium term academic, personal and professional goals. The range of graduate competencies, collectively termed 'I am UWS', are designed to support the development of specific attributes across these three dimensions. These introduce emotions attributed to enterprise education: awareness, autonomy, and achievement, which are highlighted in this paper. However, 'I am UWS' does not provide a measure for evaluating to what extent these aspects are being developed in the individual. The Entrepreneurial Scorecard confronts this.

The scorecard and multi-staged model are tools which, respectively, question and chart the emotive journey shared by educators and students. These should be considered by the former during course 
development, suitably addressing the many topics inferred, personally, professionally, and entrepreneurially. Between the two cohorts, notable differences in self-belief, leadership, and uncertainty were noted. These issues, related to personal and professional experiences and development, can be broached through greater exposure to emboldening, enterprising interventions. Thus, similar to research which has aimed to outline entrepreneurial competences and skills-attainment, this paper enables a realisation of core traits and attributes within students and aspiring entrepreneurs. In essence, this paper conceptually adds to the existing research around entrepreneurial intention and action, whilst providing new evidence of the impact of such interventions within the educational context. The approach from this paper highlights the central themes of awareness, autonomy, and achievement, raising questions of concern to educators towards the creation, maintenance, and development of an enterprise course.

\section{Recommendations}

Much of the research conducted by relevant educators centre on investigating course interventions with their own students (Blenker et al., 2014) and this study is no exception. Whilst this study focuses on the application of the scorecard to a single university, inspired by a specific set of graduate competencies, it is transferable, and of value, to other institutions. Therefore, it is recommended that each institution should tailor the scorecard questions to reflect respective graduate competencies, which support their own priorities and focus. In doing so, this will ensure that the survey has contextual meaning and relevance for any institution concerned with establishing a transition from $e P e r$ to $e$ Pro.

However, an opportunity is recognised here to potentially involve qualitative and grounded aspects of educational research, in gathering more empirical data and utilisation of this scorecard. This paper suggests that the Entrepreneurial Scorecard be applied in a longitudinal approach in order to establish if it is capable of evaluating shifts in $e P e r$ and $e P r o$ following enterprising interventions. Additionally, further study should apply the scorecard in other social spheres out with the environment of higher education such as in compulsory and further education, or in industry.

\section{References}

Ahmed, T., Rehman, I. \& Sergi, B. (2019), "A Proposed Framework on the Role of Entrepreneurial Education and Contextual Factors", Sergi, B. and Scanlon, C. (Ed.) Entrepreneurship and Development in the 21st Century (Lab for Entrepreneurship and Development), Emerald Publishing Limited, pp. 47-68. 
Ajzen, I. (1991). “The theory of planned behavior", Organ, Behavior and Human Decision Processes, 50 179-211.

Bae, T.J., Qian, S., Miao, C., \& Fiet, J.O. (2014). “The Relationship between Entrepreneurship Education and Entrepreneurial Intentions: A Meta-Analytic Review", Entrepreneurship Theory and Practice, Vol. 38 No. 2, 217-254.

Bandura, A. (1986). "The explanatory and predictive scope of self-efficacy theory", Journal of Social and Clinical Psychology, Vol. 4, 359-373.

Bird, B. (1988). "Implementing entrepreneurial ideas: The case for intention". Academy of Management Review, Vol. 13 No. 3, 442-453.

Bolton, B., and Thompson, J. (2005), "Entrepreneurs -Talent, Temperament, Technique”, Oxford: Elsevier, Butterworth-Heinemann.

Brazeal, D.V. \& Hebert, T. (1999), "The genesis of entrepreneurship", Entrepreneurship Theory and Practice, Vol. 23 No. 3, pp. 29-45.

Bridge, S. (2017). "Is "entrepreneurship" the problem in entrepreneurship education?", Education + Training, Vol. 59 No. 7/8, pp.740-750.

Burns, P. (2013) “Corporate Entrepreneurship, Innovation and strategy in large organisations”. (3rd Ed). Palgrave Macmillan.

Casson, M, (1982). “The Entrepreneur: An Economic Theory”, Totowa, N.J.: Barnes \& Noble.

Casson, M. (2010). "Entrepreneurship: theory, institutions and history", Eli F. Heckscher Lecture, 2009,Scandinavian Economic History Review, Vol. 58 No. 2, pp. 139-170.

Costa, S. F., Caetano, A., \& Santos, S. C. (2016). "Entrepreneurship as a Career Option: Do Temporary Workers Have the Competencies, Intention and Willingness to Become Entrepreneurs?" The Journal of Entrepreneurship, Vol. 25 No. 2, pp. 129-154. 
Crammond, R., Omeihe, K.O. Murray, A. and Ledger, K. (2018) 'Managing knowledge through social media: Modelling an entrepreneurial approach for Scottish SMEs and beyond'. Baltic Journal of Management. Vol. 13 No. 3, pp. 303-328.

Crammond, R. (2019) 'Progressing Enterprising Education within Universities: Asserting Principles of Stakeholder Engagement'. Journal of Higher Education Service Science and Management (JoHESSM). Vol. 2 No. 2, pp. 1-10.

Davidsson, P. (2015). "Entrepreneurial opportunities and the entrepreneurship nexus: A reconceptualization”, Journal of Business Venturing, Vol. 30 No. 5, pp. 674-695.

Drucker, P.F. (1985). “The Practice of Entrepreneurship", Innovation and Entrepreneurship Practice and Principles, Harper \& Row, New York, pp. 141-188

Duval-Couetil N. (2013). “Assessing the Impact of Entrepreneurship Education Programs: Challenges and Approaches”,.Journal of Small Business Management, Vol. 51 No. 3, pp. 394-409.

Eckhardt, J.T. and Shane, S.A. (2003). "Opportunities and entrepreneurship”, Journal of Management, Vol. 29 No. 3, pp. 333-49.

Eid, R., Badewi, A., Selim, H. \& El-Gohary, H. (2019). "Integrating and extending competing intention models to understand the entrepreneurial intention of senior university students", Education + Training, Vol. 61 No. 2, pp.234-254.

Fayolle, A. (2005). "Evaluation of entrepreneurship education: behaviour performing or intention increasing?", International Journal of Entrepreneurship and Small Business, Vol. 2 No. 1, pp. 89-98.

Fayolle, A., Gailly, B., \& Lassas-Cerc, N. (2006). "Assessing the impact of entrepreneurship education program: a new methodology”. Journal of European Industrial Training, Vol. 30 No. 9, pp. 701-720.

Fayolle, A. \& Gailly, B., (2015). "The impact of entrepreneurship education on entrepreneurial attitudes and intention: Hysteresis and persistence". Journal of small business management, Vol. 53 No. 1, pp.7593. 
Formaini, R.L. (2006). “The engine of capitalist process: entrepreneurs in economic theory”, in Price, R.W. (Ed.), Entrepreneurship, 5th ed., McGraw-Hill/Dushkin, DuBuque, IA, pp. 2-9, originally published in (2001) Federal Reserve Bank of Dallas Economic and Financial Review, 4th Quarter, pp. 2-11.

Galvão, A., Susana Marques, C. \& Peixeira Marques, C. (2018). "Antecedents of entrepreneurial intentions among students in vocational training programmes", Education + Training, Vol. 60 No. 7/8, pp.719-734.

Garavan, T. \& O'Cinneide, B. (1994). "Entrepreneurship Education and Training Programmes: ", Journal of European Industrial Training, Vol. 18 No. 8, pp. 3-12.

Grichnik, D., Brinckmann, J., Singh, L. \& Manigart, S. (2014). "Beyond environmental scarcity: Human and social capital as driving forces of bootstrapping activities". Journal of Business Venturing, Vol. 29 No. 2, pp.310-326.

Henry, C., Hill, F. \& Leitch, C. (2005). "Entrepreneurship education and training: can entrepreneurship be taught? Part I", Education + Training, Vol. 47 No. 2, pp. 98-111.

Jones, B. \& Iredale, N. (2010). "Enterprise education as pedagogy", Education + Training, Vol. 52 No. 1, pp. 7-19.

Knight, F.H., (1921). "Risk, Uncertainty, and Profit", Hart, Schaffner, and Marx Prize Essays, no. 31. Boston and New York: Houghton Mifflin.

Krueger, N., Reilly, M.D., \& Carsrud, A.L. (2000). "Competing models of entrepreneurial intentions", Journal of Business Venturing, Vol. 15, pp. 411-432.

Kuratko, D. F. (2005). “The Emergence of Entrepreneurship Education: Development, Trends, and Challenges", Entrepreneurship Theory and Practice, Vol. 29 No. 5, pp. 577-597.

Langkamp Bolton, D. \& Lane, M. (2012), "Individual entrepreneurial orientation: development of a measurement instrument", Education + Training, Vol. 54 No. 2/3, pp. 219-233. 
Liñán, F., Rodríguez-Cohard, J.C. \& Rueda-Cantuche, J.M., (2011). "Factors affecting entrepreneurial intention levels: a role for education". International entrepreneurship and management Journal, Vol. 7 No. 2, pp.195-218.

Marques, C.S., Ferreira, J.J., Gomes, D.N. \& Gouveia Rodrigues, R., (2012). "Entrepreneurship education: How psychological, demographic and behavioural factors predict the entrepreneurial intention". Education+ Training, Vol. 54 No. 8/9, pp.657-672.

Marzo-Navarro, M., Pedraja-Iglesias, M. \& Rivera-Torres, P. (2009), "Curricular profile of university graduates versus business demands", Education + Training, Vol. 51 No. 1, pp. 56-69.

Murray, A., Crammond, R, Omeihe, K.O., Scuotto, V. (2019) 'Establishing successful methods of entrepreneurship education in nurturing new entrepreneurs'. Journal of Higher Education Service Science and Management (JoHESSM). Vol. 1 No. 1, pp. 1-11.

Murray, A. (2019a). "Supporting academic entrepreneurship: a blueprint for a university based business incubator", Journal of Higher Education Service Science and Management. Vol. 1 No. 1.

Murray, A. (2019b). "The role of practical assessment in the delivery of successful enterprise education", Education + Training.

Mwasalwiba, S.E. (2010) "Entrepreneurship education: a review of its objectives, teaching methods, and impact indicators", Education + Training, Vol. 52 No. 1, pp. 20-47.

Nabi, G., Liñán, F., Fayolle, A., Krueger, N. \& Walmsley, A. (2017). “The Impact of Entrepreneurship Education in Higher Education: A Systematic Review and Research Agenda", Academy of Management Learning \& Education 2017 Vol. 16 No. 2, pp. 277-299.

Neck, C., Neck, H., Manz, C. \& Godwin, J. (1999). “I think I can; I think I can”, Journal of Managerial Psychology, Vol. 14 No. 6, pp. 477-501.

Oosterbeek, H., M. Van Praag, M \& Ysselstein, A. (2010). “The impact of entrepreneurship education on entrepreneurship skills and motivation", European Economic Review, Vol. 54 No. 3, pp. 442-454. 
Otache, I. (2019). "Entrepreneurship education and undergraduate students' self- and paid-employment intentions: A conceptual framework", Education + Training, Vol. 61 No. 1, pp.46-64.

Pinchot, G. (1986). “Intrapreneurship Revisited”, European Management Journal, Vol. 4 No. 2, pp. 89-94.

Pittaway, L., \& Cope, J. (2007). "Entrepreneurship Education: A Systematic Review of the Evidence", International Small Business Journal, Vol. 25 No. 5, pp. 479-510.

Reynolds, P.D. (1995), "Who starts new firms? Linear additive versus interaction based models", paper presented at the Babson-Kauffman Entrepreneurship Research Conference, London.

Sá, C. \& Holt, C. (2019). "Profiles of entrepreneurship students: implications for policy and practice", Education + Training, Vol. 61 No. 2, pp.122-135.

Schumpeter, J.A. (1934). "The Theory of Economic Development”, ed. R. Opie, Cambridge, MA: Harvard University Press, Business Cycles (New York: John Wiley, 1939).

Shapero, A. \& Sokol, L. (1982). “The social dimensions of entrepreneurship”, In C.A. Kent, D.L. Sexton, \& K.H. Vesper (eds.), Encyclopedia of Entrepreneurship, 72-90. Englewood Cliffs, NJ: Prentice Hall.

Shefsky, L. E. (1994). “Entrepreneurs are Made not Born”, New, York:McGraw-Hill.

Schwarz, E., Wdowiak, M., Almer-Jarz, D. \& Breitenecker, R. (2009), "The effects of attitudes and perceived environment conditions on students' entrepreneurial intent", Education + Training, Vol. 51 No. 4, pp. 272-291.

Souitaris, V., Zerbinati, S. \& Al-Laham, A., (2007). "Do entrepreneurship programmes raise entrepreneurial intention of science and engineering students: The effect of learning, inspiration and resources". Journal of Business venturing, Vol. 22 No. 4, pp.566-591.

Taatila, V. (2010). "Learning entrepreneurship in higher education", Education + Training, Vol. 52 No. 1, pp. $48-61$. 
Ustav, S. \& Venesaar, U. (2018). "Bridging metacompetencies and entrepreneurship education", Education + Training, Vol. 60 No. 7/8, pp.674-695.

Von Graevenitz, G., Harhoff, D \& Weber, R., (2010). “The effects of entrepreneurship education”, Journal of Economic Behavior \& Organization, Vol. 76, pp. 90-112.

Zhang, Y., Duysters, G. \& Cloodt, M., (2014). "The role of entrepreneurship education as a predictor of university students' entrepreneurial intention". International entrepreneurship and management journal, Vol. 10 No. 3, pp.623-641.

\section{Appendix}

Table 2 The Entrepreneurial Scorecard: Questions by Theme

\begin{tabular}{|c|c|c|c|}
\hline \multicolumn{2}{|c|}{ Entrepreneurial Journey Stage } & $\begin{array}{r}\text { Questions } \\
\end{array}$ & Associated Theme \\
\hline $\begin{array}{c}\text { Start } \\
\text { (Preliminary) }\end{array}$ & $\begin{array}{l}\text { Programme Introduction } \\
\text { \& Topical Orientation }\end{array}$ & $\begin{array}{l}\text { Question } 1 \text { How motivated are you? } \\
\text { Question } 2 \text { How comfortable are you with taking risks? } \\
\text { Question } 3 \text { Are you a leader? } \\
\text { Question } 6 \text { Are you willing to work } 50 \text { hours a week, or more? } \\
\text { Question } 8 \text { Can you live with high levels of uncertainty? }\end{array}$ & Awareness \\
\hline 1 & Creative Activities & $\begin{array}{l}\text { Question } 7 \text { Do you have belief in your ability to succeed? } \\
\text { Question } 9 \text { Can you stick with something once you have put your mind to it? } \\
\text { Question } 10 \text { Are you creative? } \\
\text { Question } 13 \text { Are you individualistic? }\end{array}$ & Awareness \\
\hline 2 & $\begin{array}{c}\text { Innovative / } \\
\text { Developmental Activities }\end{array}$ & $\begin{array}{l}\text { Question } 11 \text { Are you competitive? } \\
\text { Question } 14 \text { Can you live without structure? } \\
\text { Question } 16 \text { Are you flexible and willing to change course when things are not } \\
\text { going well? } \\
\text { Question } 19 \text { Are you willing to go out and personally sell to get customers? } \\
\text { Question } 23 \text { Are you a problem solver? }\end{array}$ & Autonomy \\
\hline 3 & $\begin{array}{l}\text { Entrepreneurial/ } \\
\quad \text { Planning \& } \\
\text { Coordinating Activities }\end{array}$ & $\begin{array}{l}\text { Question } 4 \text { Would you be comfortable living without a regular income for a } \\
\text { time? } \\
\text { Question } 5 \text { Could you fire someone who really needed the job you provide? } \\
\text { Question } 12 \text { Do you have a lot of willpower and self-discipline? } \\
\text { Question } 15 \text { Do you have much business experience? } \\
\text { Question } 17 \text { Do you have skills that would be useful in business? } \\
\text { Question } 18 \text { Are you a multi-tasker? } \\
\text { Question } 21 \text { How comfortable would you be managing staff? } \\
\text { Question } 22 \text { How comfortable are you with taking orders from management? }\end{array}$ & Autonomy \\
\hline Finish & $\begin{array}{c}\text { Assessment / Impact \& } \\
\text { Reflection }\end{array}$ & $\begin{array}{l}\text { Question } 20 \text { How well do you handle pressure? } \\
\text { Question } 24 \text { How well do you take advice? } \\
\text { Question } 25 \text { Can you ever imagine yourself running your own business? }\end{array}$ & Achievement \\
\hline
\end{tabular}


Table 3 Recorded Scorecard Scores

\begin{tabular}{|c|c|c|c|c|}
\hline \multirow[t]{2}{*}{ Question } & \multicolumn{2}{|c|}{ Cohort 1} & \multicolumn{2}{|c|}{ Cohort 2} \\
\hline & Before & After & Before & After \\
\hline 1 & 55 & 68 & 81 & 81 \\
\hline 2 & 55 & 70 & 54 & 63 \\
\hline 3 & 78 & 66 & 66 & 74 \\
\hline 4 & 68 & 65 & 65 & 67 \\
\hline 5 & 71 & 81 & 63 & 65 \\
\hline 6 & 57 & 54 & 66 & 70 \\
\hline 7 & 67 & 66 & 60 & 63 \\
\hline 8 & 77 & 65 & 82 & 85 \\
\hline 9 & 66 & 63 & 62 & 65 \\
\hline 10 & 65 & 66 & 64 & 67 \\
\hline 11 & 64 & 75 & 62 & 66 \\
\hline 12 & 67 & 78 & 61 & 63 \\
\hline 13 & 61 & 82 & 77 & 79 \\
\hline 14 & 70 & 77 & 74 & 77 \\
\hline 15 & 81 & 80 & 79 & 80 \\
\hline 16 & 59 & 76 & 78 & 80 \\
\hline 17 & 64 & 88 & 71 & 73 \\
\hline 18 & 60 & 80 & 58 & 83 \\
\hline 19 & 78 & 81 & 57 & 71 \\
\hline 20 & 67 & 80 & 60 & 75 \\
\hline 21 & 77 & 80 & 73 & 83 \\
\hline 22 & 80 & 77 & 64 & 81 \\
\hline 23 & 80 & 85 & 71 & 88 \\
\hline 24 & 70 & 82 & 74 & 85 \\
\hline 25 & 70 & 80 & 67 & 85 \\
\hline 26 & 85 & 74 & & \\
\hline 27 & 82 & 82 & & \\
\hline 28 & 66 & 82 & & \\
\hline 29 & 79 & 75 & & \\
\hline 30 & 76 & 82 & & \\
\hline 31 & 63 & 78 & & \\
\hline 32 & 66 & 73 & & \\
\hline 33 & 70 & 75 & & \\
\hline 34 & 70 & 78 & & \\
\hline 35 & 75 & 83 & & \\
\hline 36 & 67 & 81 & & \\
\hline 37 & 75 & 80 & & \\
\hline 38 & 73 & 76 & & \\
\hline 39 & 75 & 76 & & \\
\hline 40 & 72 & 82 & & \\
\hline 41 & 61 & 73 & & \\
\hline 42 & 65 & 78 & & \\
\hline 43 & 65 & 73 & & \\
\hline 44 & 76 & 80 & & \\
\hline 45 & 69 & 77 & & \\
\hline 46 & 69 & 74 & & \\
\hline 47 & 70 & 78 & & \\
\hline 48 & 70 & 76 & & \\
\hline 49 & 72 & 76 & & \\
\hline 50 & 69 & 80 & & \\
\hline $\begin{array}{c}\text { Total } \\
\text { Averages }\end{array}$ & 69.74 & 76.14 & 67.56 & 74.76 \\
\hline
\end{tabular}


Table 4 Average Question Scores

\begin{tabular}{ccccc}
\hline Question & \multicolumn{2}{c}{ Cohort 1 } & \multicolumn{2}{c}{ Cohort 2 } \\
\cline { 2 - 5 } $\mathbf{1}$ & Before & After & Before & After \\
\cline { 2 - 5 } $\mathbf{2}$ & 3.06 & 3.06 & 2.84 & $\mathbf{3 . 2 8}$ \\
$\mathbf{3}$ & 2.72 & $\mathbf{3 . 3 6}$ & 2.84 & $\mathbf{3 . 0 8}$ \\
$\mathbf{4}$ & $\mathbf{2 . 7}$ & 2.58 & 2.72 & $\mathbf{3 . 0 0}$ \\
$\mathbf{5}$ & 1.7 & $\mathbf{2 . 5 8}$ & 1.96 & $\mathbf{2 . 2 0}$ \\
$\mathbf{6}$ & $\mathbf{2 . 7 2}$ & 2.48 & 2.44 & $\mathbf{2 . 7 6}$ \\
$\mathbf{7}$ & 2.78 & 2.78 & 2.6 & $\mathbf{2 . 8 0}$ \\
$\mathbf{8}$ & 3.06 & $\mathbf{3 . 3 4}$ & 3.12 & $\mathbf{3 . 4 0}$ \\
$\mathbf{9}$ & 2.36 & $\mathbf{2 . 3 8}$ & 2.32 & $\mathbf{2 . 4 4}$ \\
$\mathbf{1 0}$ & 3 & $\mathbf{3 . 0 2}$ & 2.72 & $\mathbf{3 . 3 2}$ \\
$\mathbf{1 1}$ & 2.44 & $\mathbf{2 . 8 6}$ & 2.36 & $\mathbf{2 . 6 8}$ \\
$\mathbf{1 2}$ & 2.66 & $\mathbf{3 . 1 6}$ & 3 & $\mathbf{3 . 2 8}$ \\
$\mathbf{1 3}$ & 2.62 & $\mathbf{3 . 4 4}$ & 3.04 & $\mathbf{3 . 1 2}$ \\
$\mathbf{1 4}$ & 2.46 & $\mathbf{3 . 2 4}$ & 2.84 & $\mathbf{3 . 1 2}$ \\
$\mathbf{1 5}$ & $\mathbf{2 . 6 2}$ & 2.5 & 2.12 & $\mathbf{2 . 4 4}$ \\
$\mathbf{1 6}$ & 2.38 & $\mathbf{2 . 5 6}$ & 2.08 & $\mathbf{2 . 4 0}$ \\
$\mathbf{1 7}$ & 3.26 & $\mathbf{3 . 5 6}$ & 3.04 & $\mathbf{3 . 4 0}$ \\
$\mathbf{1 8}$ & $\mathbf{3}$ & 2.84 & 2.92 & $\mathbf{3 . 1 2}$ \\
$\mathbf{1 9}$ & 3.14 & $\mathbf{3 . 1 8}$ & 2.32 & $\mathbf{2 . 7 6}$ \\
$\mathbf{2 0}$ & 2.48 & $\mathbf{3 . 2 2}$ & 2.52 & $\mathbf{2 . 8 4}$ \\
$\mathbf{2 1}$ & 3.24 & $\mathbf{3 . 3}$ & 3.16 & $\mathbf{3 . 2 4}$ \\
$\mathbf{2 2}$ & 3.16 & $\mathbf{3 . 3 4}$ & 2.88 & $\mathbf{3 . 2 8}$ \\
$\mathbf{2 3}$ & 3.34 & $\mathbf{3 . 4 2}$ & 2.84 & $\mathbf{3 . 0 8}$ \\
$\mathbf{2 4}$ & $\mathbf{3 . 1 6}$ & 3.04 & 2.76 & $\mathbf{3 . 1 2}$ \\
$\mathbf{2 5}$ & 2.74 & $\mathbf{3 . 3 8}$ & 2.76 & $\mathbf{3 . 1 6}$ \\
\hline Total & 2.94 & $\mathbf{3 . 5 2}$ & 3.36 & $\mathbf{3 . 4 4}$ \\
Averages & $\mathbf{2 . 7 9}$ & $\mathbf{3 . 0 5}$ & $\mathbf{2 . 7 0}$ & $\mathbf{2 . 9 9}$ \\
& & & & \\
\hline
\end{tabular}


Table 5 t-Test, per cohort

t-Test: Paired Two Sample for

Means

Cohort 1

\begin{tabular}{lrr}
\hline & Before & \multicolumn{1}{c}{ After } \\
\hline Mean & 2.7896 & 3.0456 \\
Variance & 0.139270667 & 0.13381733 \\
Observations & 25 & 25 \\
Pearson Correlation & 0.554832923 & \\
Hypothesized Mean Difference & 0 & \\
df & 24 & \\
t Stat & - & \\
$\mathbf{P}(\mathbf{T}<=t)$ one-tail & 3.670651742 & \\
t Critical one-tail & 0.000602761 & \\
$\mathbf{P}(\mathbf{T}<=t)$ two-tail & 1.71088208 & \\
t Critical two-tail & 0.001205523 & \\
\hline
\end{tabular}

t-Test: Paired Two Sample for

Means

Cohort 2

\begin{tabular}{lrr} 
& & \\
\hline Mefore & \multicolumn{1}{c}{ After } \\
Variance & 2.7024 & 2.9904 \\
Observations & 0.128944 & 0.121370667 \\
Pearson Correlation & 25 & 25 \\
Hypothesized Mean Difference & 0.939706624 & \\
df & 0 & \\
& 24 & \\
t Stat & - & \\
P(T<=t) one-tail & 11.67994232 & \\
t Critical one-tail & $1.09138 \mathrm{E}-11$ & \\
P(T<=t) two-tail & 1.71088208 & \\
t Critical two-tail & $2.18276 \mathrm{E}-11$ & \\
\hline
\end{tabular}


Tables 6 and 7 Question Tendency Correlation: Cohort 1 and 2

\begin{tabular}{|c|c|c|c|c|c|c|c|c|c|c|c|c|c|c|c|c|c|c|c|c|c|c|c|c|c|}
\hline$Q$ & 1 & 2 & 3 & 4 & 5 & 6 & 9 & 8 & , & 10 & 11 & 12 & 13 & 14 & 15 & 16 & 17 & 18 & 19 & 20 & a & : & 23 & 24 & 26 \\
\hline 1 & 1.000 & & & & & & & & & & & & & & & & & & & & & & & & \\
\hline : & -0.004 & 1.000 & & & & & & & & & & & & & & & & & & & & & & & \\
\hline 3 & 0.338 & -0.023 & 1.000 & & & & & & & & & & & & & & & & & & & & & & \\
\hline 4 & 0.237 & 0.390 & 0.008 & 1000 & & & & & & & & & & & & & & & & & & & & & \\
\hline$t$ & -0.093 & 0.126 & 0.314 & .0 .159 & 1000 & & & & & & & & & & & & & & & & & & & & \\
\hline 6 & 0.119 & -0.090 & 0.083 & 0.166 & 0.041 & 1.000 & & & & & & & & & & & & & & & & & & & \\
\hline 7 & 0.349 & 0.259 & 0.058 & 0.473 & 0.185 & -0.264 & 1.000 & & & & & & & & & & & & & & & & & & \\
\hline 8 & -0.115 & -0.281 & 0.074 & 0.061 & 0.233 & 0.221 & .0 .119 & 1000 & & & & & & & & & & & & & & & & & \\
\hline , & 0.095 & 0.074 & 0.114 & 0.140 & 0.050 & $0.24 !$ & .0 .102 & 0.171 & 1.000 & & & & & & & & & & & & & & & & \\
\hline 10 & 0.199 & 0.149 & 0.130 & 0.076 & 0.074 & 0.273 & 0.189 & 0.259 & 0.194 & 1000 & & & & & & & & & & & & & & & \\
\hline 11 & 0.177 & 0.285 & 0.169 & 0.260 & 0.210 & 0.045 & 0.217 & 0.143 & -0.010 & 0.12 & 1000 & & & & & & & & & & & & & & \\
\hline 1: & 0.102 & 0.14 & 0.263 & 0.116 & 0.326 & 0.245 & -0.028 & 0.015 & 0.400 & 0.304 & -0.042 & 1.000 & & & & & & & & & & & & & \\
\hline 13 & 0.017 & 0.214 & 0.304 & 0.304 & 0.053 & -0.068 & 0.163 & .0 .064 & 0.245 & 0002 & 0.242 & $0.1 \mathrm{ss}$ & 1000 & & & & & & & & & & & & \\
\hline 14 & 0.063 & 0.000 & 0.106 & 20.053 & 0.390 & 0.36 & 0.295 & 0.24 & 0.054 & 0.325 & 0.000 & 0.335 & 0.186 & 1.000 & & & & & & & & & & & \\
\hline 15 & 0.094 & 0.136 & 0.114 & 0.232 & 0.424 & 0.210 & -0.020 & 0.289 & 0.020 & 0.064 & 0.189 & 0.264 & 0.194 & 0.255 & 1000 & & & & & & & & & & \\
\hline 16 & 0.087 & 0.124 & -0053 & 0.098 & 0.026 & 0.064 & -0.094 & -0.119 & 0.253 & 0.103 & 0.152 & 0.202 & 0.021 & 0.052 & 0.166 & 1000 & & & & & & & & & \\
\hline 17 & 0.185 & 0.059 & 0.059 & 0.423 & 0.147 & 0.190 & .0415 & - toss & 0.516 & 0.005 & 0.121 & 0.154 & $\rightarrow \cos$ & 0.209 & 0.062 & 0097 & 1000 & & & & & & & & \\
\hline is & 0319 & 0.361 & 0.145 & 0.409 & 0.198 & -0.128 & 0.566 & 0.166 & 0.158 & 0.085 & 0.078 & 0.175 & 0.372 & 0.22 & 0.056 & 0.278 & -0.286 & 1000 & & & & & & & \\
\hline 19 & 0.328 & 0.353 & 0.074 & 0.099 & 0.057 & -0.135 & 0.264 & 0.405 & 0.147 & -0.200 & -0.104 & 0.316 & 0.068 & 0.018 & 0.267 & 0.433 & 0.034 & 0.413 & 1.000 & & & & & & \\
\hline 20 & 0.166 & -0.074 & 0.180 & 0.241 & 0.069 & 0.014 & 0.247 & 0.343 & 0.033 & 0.045 & 0.043 & 0.086 & 0.263 & 0.021 & 0.188 & -0.026 & 0.129 & 0.202 & 0.167 & 1000 & & & & & \\
\hline 21 & 0.235 & 0.283 & 0.159 & 0.157 & 0.134 & -0.162 & 0.346 & 0.22 & 0.136 & -0.030 & 0.022 & 0.17 & 0.192 & -0.162 & 0.112 & 0.108 & 0.043 & 0.459 & 0.411 & -0.125 & 1.000 & & & & \\
\hline : & 0.094 & 0.053 & 0.155 & 0.038 & 0.113 & 0.074 & -0.007 & 0.112 & 0.262 & 0.307 & 0.046 & 0.233 & 0.299 & 0.149 & 0.134 & 0.216 & 0.020 & 0.430 & 0.199 & 0.420 & 0.112 & 1.000 & & & \\
\hline 23 & -0.115 & 0.175 & 0.009 & 0.039 & 0.275 & 0.158 & 0.086 & 0.19 & 0.518 & 0.032 & 0.049 & 0.257 & 0.335 & 0.085 & 0.327 & 0.328 & 0.345 & 0.257 & 0.163 & 0.187 & 0.140 & 0.175 & 1.000 & & \\
\hline 24 & 0.052 & 0.052 & 0.230 & 0.155 & 0.159 & 0.045 & .0 .020 & 0.087 & 0.418 & 0.211 & -0.063 & 0.241 & 0.073 & 0.19 & 0.290 & 0.357 & 0.412 & 0.145 & 0.452 & 0.380 & 0.229 & 0.417 & 0.290 & 1.000 & \\
\hline$: 6$ & 0.459 & 0.412 & 0.243 & 0.244 & 0018 & 0.175 & 0.465 & 0.197 & .0 .106 & -0.373 & 0.119 & 0.025 & 004 ! & 0.382 & 0.016 & 00087 & 0.138 & 0.460 & $0.46 !$ & 0.157 & 0.333 & .0046 & 0.052 & 0.047 & 1000 \\
\hline
\end{tabular}

Page $\mathbf{2 9}$ of $\mathbf{3 2}$ 


\begin{tabular}{|c|c|c|c|c|c|c|c|c|c|c|c|c|c|c|c|c|c|c|c|c|c|c|c|c|c|}
\hline Q & 1 & : & 3 & 4 & 5 & 6 & 1 & 8 & 9 & 10 & II & 1: & 13 & 14 & 16 & 16 & 17 & 18 & 19 & 20 & 21 & : & 23 & 24 & 26 \\
\hline 1 & 1000 & & & & & & & & & & & & & & & & & & & & & & & & \\
\hline : & 0.196 & 1.000 & & & & & & & & & & & & & & & & & & & & & & & \\
\hline 3 & $0.2 n$ & 0.388 & 1.000 & & & & & & & & & & & & & & & & & & & & & & \\
\hline 4 & 0.562 & 0.435 & 0.214 & 1000 & & & & & & & & & & & & & & & & & & & & & \\
\hline 5 & 0.225 & 0.49 & 0.17 & 0.365 & 1000 & & & & & & & & & & & & & & & & & & & & \\
\hline 6 & 0.548 & 0.186 & 0.000 & 0.214 & 0.460 & 1.000 & & & & & & & & & & & & & & & & & & & \\
\hline 9 & 0.368 & 0.018 & 0.234 & 0.085 & 0.307 & 0.085 & 1.000 & & & & & & & & & & & & & & & & & & \\
\hline 8 & 0.186 & 0.317 & -0.094 & 0.356 & 0.513 & 0.487 & .0 .044 & 1000 & & & & & & & & & & & & & & & & & \\
\hline 9 & 0.159 & 0.034 & 0.174 & 0.298 & 0.497 & 0.052 & 0.597 & 0.169 & 1.000 & & & & & & & & & & & & & & & & \\
\hline 10 & 0.185 & 0.0ss & 0.395 & 0.284 & 0000 & 0.032 & 0.112 & 0.084 & 0.246 & 1.000 & & & & & & & & & & & & & & & \\
\hline II & 0.337 & 0.213 & 0.453 & 0.209 & 0.178 & 0.273 & 0.495 & .0 .005 & 0.220 & 0.258 & 1.000 & & & & & & & & & & & & & & \\
\hline 1: & 0.065 & 0.226 & 0.075 & 0.256 & 0.231 & 0.120 & 0.071 & 0.165 & 0.095 & 0.163 & 0.095 & 1.000 & & & & & & & & & & & & & \\
\hline 13 & 0.012 & .0 .094 & 0.070 & 0.251 & OOA2 & 0.112 & 0.231 & 0.062 & 0.259 & 0.151 & 0.327 & .0 .173 & 1000 & & & & & & & & & & & & \\
\hline 14 & 0.339 & 0.000 & 0.000 & 0.319 & 0.235 & 0.412 & 0.047 & 0.362 & 0.201 & .0 .109 & 0.069 & 0.232 & 0.021 & 1.000 & & & & & & & & & & & \\
\hline 15 & 0.117 & 0.021 & 0.567 & 0.094 & 0.265 & 0.094 & 0.000 & 0.074 & 0.092 & 0.125 & 0.234 & -0.219 & 0.018 & 0.405 & 1000 & & & & & & & & & & \\
\hline 16 & 0.020 & 0.432 & 0.472 & 0.283 & 0.655 & 0.189 & 0335 & 0.322 & 0.437 & 0.230 & 0.234 & 0.179 & 0.074 & 0.141 & 0.250 & 1000 & & & & & & & & & \\
\hline 17 & 0.168 & 0.307 & 0.301 & 0.331 & 0.293 & 0.271 & 0.160 & 0.362 & 0.187 & 0.412 & 0.183 & 0.604 & 0.247 & -0.092 & -0.020 & 0.477 & 1000 & & & & & & & & \\
\hline is & 0.408 & 0.031 & 0.295 & 0.365 & 0.167 & 0.071 & 0.058 & 0.121 & 0.006 & 0.396 & 0.112 & -0.328 & o.en & $\$ 0.020$ & 0.343 & 0.031 & 0.017 & 1000 & & & & & & & \\
\hline 19 & 0.464 & 0.264 & 0.292 & 0.278 & 0.425 & 0.600 & 0.223 & 0.360 & 0.203 & 0.104 & 0.339 & 0.27 & 0.034 & 0.460 & 0.251 & 0.445 & 0.037 & 0.063 & 1.000 & & & & & & \\
\hline 20 & 0.209 & 0.043 & 0.302 & 0.317 & 0.090 & 0.211 & 0.500 & 0.162 & 0.099 & 0.077 & 0.282 & 0.102 & 0.094 & 0.396 & 0.160 & 0.160 & 0.02 & 0.090 & 0.080 & 1000 & & & & & \\
\hline :1 & 0.375 & 0.057 & 0.476 & 0.429 & -0.130 & -0.071 & 0.169 & 0.012 & 0.255 & 0.558 & 0.273 & 0.020 & 0.251 & 0.102 & 0.189 & 0.189 & 0.271 & 0.460 & 0.136 & -0.211 & 1000 & & & & \\
\hline : & 0.540 & .0120 & 0.191 & 0.248 & 0.117 & -0.057 & 0.248 & 0.015 & 0.274 & 0.279 & 0.155 & -0.426 & 0.258 & 0.100 & 0.404 & 0.152 & $\rightarrow 125$ & 0.589 & 0.031 & 0.153 & 0.229 & 1.000 & & & \\
\hline a & 0.065 & 0.226 & 0.301 & 0.180 & 0.417 & 0.120 & 0.160 & 0.165 & 0.278 & 0.163 & 0.352 & 0.288 & 0.194 & .0372 & 0,050 & 0.477 & 0.258 & 0.045 & 0.191 & 0.340 & 0.145 & 0.17 & 1.000 & & \\
\hline$: 4$ & 0.274 & 0.421 & 0.546 & 0.423 & 0.279 & 0.055 & 0.274 & 0.111 & 0.226 & 0.247 & 0.068 & 0.037 & 0.165 & 0.015 & 0.397 & 0.397 & 0.181 & 0.445 & 0.394 & 0.291 & 0.441 & 0.244 & 0.324 & 1000 & \\
\hline$: t$ & 0.254 & 0.740 & 0.419 & 0.319 & 0.321 & $0.1 \mathrm{H}$ & 0.159 & 0.127 & 0.099 & 0.048 & 0.370 & 0.413 & 0.190 & 0.144 & .0044 & 0.399 & 0.413 & 0.025 & 0.237 & 0.120 & 0.129 & -0.211 & 0.236 & 0.339 & 1.000 \\
\hline
\end{tabular}

Page $\mathbf{3 0}$ of $\mathbf{3 2}$ 
Table 8 Hypothetical Analysis

\begin{tabular}{|c|c|c|c|c|}
\hline \multirow{2}{*}{ Hypothesis } & \multirow{2}{*}{ Questioning by Theme } & \multirow{2}{*}{$\begin{array}{c}\text { Testing (Course Intervention = } \\
\text { CD) }\end{array}$} & \multicolumn{2}{|c|}{ Correlation } \\
\hline & & & Cohont 1 & Cohort 2 \\
\hline \multirow{4}{*}{$\begin{array}{l}\text { HP1 - Proclinity fowards } \\
\text { contimied creathve and ldea } \\
\text { generating acthities } \\
\text { moroase, at and course } \\
\text { stage. }\end{array}$} & \multirow{5}{*}{ 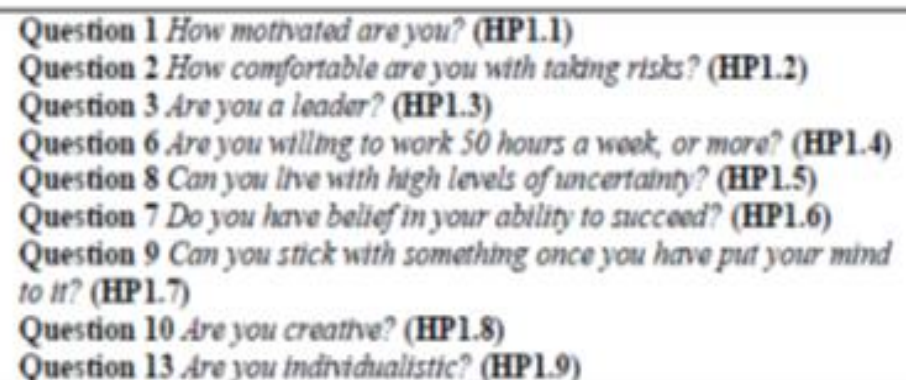 } & $\mathrm{HP1.1} \rightarrow \mathrm{Cl} \rightarrow \mathrm{HP1} .9$ & 0.017 & 0.012 \\
\hline & & $\mathrm{HP} 1.2 \rightarrow \mathrm{Cl} \rightarrow \mathrm{HP} 1.5$ & -0.281 & 0.317 \\
\hline & & $\mathrm{HP1} .3 \rightarrow \mathrm{Cl} \rightarrow \mathrm{HP} 1.7$ & 0.114 & 0.174 \\
\hline & & $\mathrm{HP} 1.4 \rightarrow \mathrm{Cl} \rightarrow \mathrm{HP} 1.6$ & -0.264 & 0.085 \\
\hline Awareness & & $\mathrm{HP1} .6 \rightarrow \mathrm{Cl} \rightarrow \mathrm{HP} 1.8$ & -0.189 & 0.112 \\
\hline \multirow{5}{*}{$\begin{array}{l}\text { HP2 - Bitreprenenorial } \\
\text { planning and perceptions of } \\
\text { market awareness and } \\
\text { accommodating mereased } \\
\text { risk increase, at end course } \\
\text { stage. }\end{array}$} & \multirow{3}{*}{$\begin{array}{l}\text { Question } 11 \text { Are you competithe? (HP2.1) } \\
\text { Question } 14 \text { Can you inve without struchure? (HP2.2) } \\
\text { Question } 16 \text { Are you flexble and willing to change course when things } \\
\text { are not going well? (HP2.3) }\end{array}$} & $\mathrm{HP} 2.1 \rightarrow \mathrm{Cl} \rightarrow \mathrm{HP} 2.4$ & -0.104 & 0.339 \\
\hline & & $\mathrm{HP} 2.2 \rightarrow \mathrm{Cl} \rightarrow \mathrm{HP} 2.6$ & -0.053 & 0.319 \\
\hline & & $\mathrm{HP} 2.3 \rightarrow \mathrm{Cl} \rightarrow \mathrm{HP} 2.5$ & 0.328 & 0.477 \\
\hline & $\begin{array}{l}\text { Question } 19 \text { Are you willing to go out and personally sell to get } \\
\text { customers? (HP2.4) }\end{array}$ & $\mathrm{HP} 2.7 \rightarrow \mathrm{Cl} \rightarrow \mathrm{HP} 2.12$ & -0.134 & -0.130 \\
\hline & Question 23 Are you a problem solver? (HP2.5) & $\mathrm{HP} 2.8 \rightarrow \mathrm{Cl} \rightarrow \mathrm{HP} 2.10$ & 0.154 & 0.604 \\
\hline \multirow[t]{2}{*}{ Autonomy } & $\begin{array}{l}\text { Question } 4 \text { Would you be comfortable lining without a regular income } \\
\text { for a time? (HP2.6) }\end{array}$ & $\mathrm{HP} 29 \rightarrow \mathrm{Cl} \rightarrow \mathrm{HP} 211$ & 0.056 & 0.343 \\
\hline & $\begin{array}{l}\text { Question } 5 \text { Could you fire someone who raally neoded the job you } \\
\text { provide? (HP2.7) } \\
\text { Question } 12 \text { Doyou have a lor of willpower and self-discipline? (HP2.8) } \\
\text { Question } 15 \text { Do you have much business apperience? (HP2.9) } \\
\text { Question } 17 \text { Do you have skills that would be usefil in business? } \\
\text { (HP2.10) } \\
\text { Question } 18 \text { Are you a multh-tasker? (HP2.11) } \\
\text { Question } 21 \text { How comfortable would you be managing staf? (HP2.12) } \\
\text { Question } 22 \text { How comfortable are you with talting orders from } \\
\text { management? (HP2.13) }\end{array}$ & $\mathrm{HP} 2.10 \rightarrow \mathrm{CI} \rightarrow \mathrm{HP} 213$ & 0.020 & -0.125 \\
\hline \multirow{3}{*}{$\begin{array}{l}\text { HP3 - Shidents' proclinity } \\
\text { towards contimued small } \\
\text { busthess and } \\
\text { entrepremearialism } \\
\text { imcruases, at end course } \\
\text { stage. }\end{array}$} & \multirow{4}{*}{$\begin{array}{l}\text { Question } 20 \text { How well do you handle pressire? (HP3.1) } \\
\text { Question } 24 \text { How well do you take advice? (HP3.2) } \\
\text { Question } 25 \text { Can you wer imagine yourself noning your own business? } \\
\text { (HP3.3) }\end{array}$} & $\mathrm{HP} 3.1 \rightarrow \mathrm{Cl} \rightarrow \mathrm{HP} 3.2$ & 0.380 & 0.291 \\
\hline & & $\mathrm{HP} 3.2 \rightarrow \mathrm{Cl} \rightarrow \mathrm{HP} 3.3$ & 0.047 & 0.339 \\
\hline & & $\mathrm{HP} 3.3 \rightarrow \mathrm{Cl} \rightarrow \mathrm{HP} 3.1$ & 0.157 & 0.120 \\
\hline Achinement & & & & \\
\hline
\end{tabular}


